\title{
The Impact of Energy Poverty on the Level of Social Security
}

\author{
Katarzyna Świerszcz \\ Military University of Technology, Warsaw \\ Warsaw, Poland \\ e-mail: katarzyna.swierszcz@ wat.edu.pl
}

\begin{abstract}
This paper attempts to analyze the impact of energy poverty in terms of heat energy on the level of social security of Polish households being a sample and an indicator of the level of energy security. The issue is presented in three aspects:
\end{abstract}

- Attempt to explain the concept of energy poverty;

- $\quad$ Factors affecting the level of energy poverty in terms of heat energy;

- How consequences of energy poverty influence the level of social security.

To deepen the problem, the research was carried out using survey and analytical-synthetic methods.

Keywords-energy poverty; heat energy; social security; consequences of energy poverty

\section{INTRODUCTION}

It is natural that the existence of a human, social groups, nations and individual states expresses the need for safety. It means not only military or political security, but also social security understood as a state of being free from ontological threats (negative aspect) and protection of existential foundations of human life together with the possibility of fulfilling one's individual needs, both material and nonmaterial, by creating conditions for work and study (positive aspect). Today it is unquestionably sure that social security constitutes the basic value of "conditio sine qua non" ("a condition without which it could not be"), without which we cannot create other goods. It is particularly critical in terms of dynamical changes that are visible both in the global economy and in the individual countries at the local level. The growing economy and the desire to improve the quality of social life are increasingly dependent on free access to energy, including heat. Meanwhile, as the research and experience of Polish households show, more and more of their inhabitants are beginning to experience the phenomenon of energy poverty - so far unknown and investigated from the scientific point of view.

Therefore, the aim of this article is to try to answer some important questions: what is the energy poverty and what factors influence its increase, and what are the consequences. of energy poverty on the level of social security among Polish households.

Answers to these questions will allow us to properly develop a public policy strategy, as well as to select the appropriate instruments understood as operational forms of public intervention aimed at complex problem solving of this phenomenon and thus affecting the level of social security.

\section{THE PHENOMENON OF ENERGY POVERTY - AN ATTEMPT TO DEFINE IT}

The energy poverty is a relatively new little-investigated term without one clear definition - despite being an increasingly common phenomenon. The United Kingdom and Ireland are the initial precursors in the study of energy poverty. Among the rest of the European Union countries those two have the greatest experience on their scientific and pragmatic market and provide clearly visible effects in the fight against this phenomenon. Among many proposed definitions one by $\mathbf{J}$. Hill is especially important. It is called Low Income High Costs (LIHC) and says that households which spend more than 10 percent of their income on sufficient level of heating are considered to suffer from energy poverty [1]. The above meaning of energy poverty is based on two criteria: low household income (falling below $60 \%$ of median equated income per household member) and high energy costs (exceeding median equated energy costs). Those two criteria currently represent a model indicator of energy poverty and the most effective measure for the accurate identification of target groups of the relevant public policies in particular European Union countries [2]. This is shown on Figure 1 below.

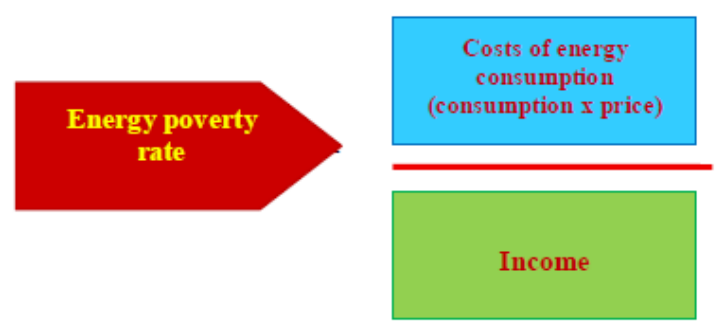

Figure 1. Model indicator of energy poverty.

At the same time, it should be noted that due to the significant differences in the incomes of the European Union residents, the poverty line varies from country to country. In 2013 the poverty threshold for a single-person household in the European Union was equal to 14,000 PPS Purchasing Power Standard with the highest poverty threshold in the amount of eight the lowest poverty thresholds. The highest value of poverty line was observed in Luxembourg (16,000 PPS - Purchasing Power Standard), Austria and Cyprus (appr. 12,000 PPS - Purchasing Power 
Standard) while the lowest ones were observed in Romania (2,100 PPS - Purchasing Power Standard), Latvia and Bulgaria (3,400 PPS - Purchasing Power Standard). The relative poverty threshold for a single-person household in Poland in 2014 was equal to 12,000 zlotys of an annual income which, after taking into account price differences in the European Union, was equivalent to 4,900 PPSPurchasing Power Standard. The threshold of income poverty in Poland after adjusting price differences was more than twice as high as in Romania, three times lower than in Luxembourg and about twice lower than in Great Britain, Germany and France [3]. Base on that criterion (LIHC Low Income High Costs), in 2014 17.1\% of Polish households, i.e. $6.4 \mathrm{mln}$ people in Poland were regarded to be affected by poverty [4].

There are some more definitions of energy poverty complementary to the British one. One of them is a common definition developed in 2009 in the international project "European Fuel Poverty and Energy Efficiency" carried out by the organizations from several European countries. This definition says that energy poverty is a phenomenon that involves experiencing difficulties in maintaining an adequate standard of living at a reasonable price [5]. However, this general definition draws attention to several important issues in fact being failures in meeting basic human needs. These are: difficulty in keeping comfortable room temperature by the household (cold in summer, warm in winter), difficulty in paying for energy bills, difficulty in repairing broken heating system and difficulty in modernizing or installing a completely new one.

We can also find many various definitions in Polish literature of the field. Each of them draws attention to other aspect and range of poverty using various criteria and poverty indicators, such as absolute poverty, relative poverty, statutory poverty, subjective poverty, objective poverty, subsistence minimum, material deprivation and others. For instance D. Owczarek and A. Miazga define energy poverty as a phenomenon consisting in "experiencing difficulties in satisfying basic energy needs at one's place of residence at a reasonable price. These include: maintaining an adequate heating standard and supply of other sources of energy used to adequately satisfy basic biological and social needs of household members [6]. The statutory adequate heating standard for Polish dwellings is 21 degrees Celsius and for other rooms 18. So if achieving the above heat temperature and meeting other basic energy needs such as lighting, cooking, using basic household appliances requires spending more than $10 \%$ of one's income, then we regard it as energy poverty [7].

To sum up, we can say that the analysis of energy poverty research clearly shows that its definition is relative and an extremely dynamic process that depends on many factors, such as economic, technological, technical, awareness and political. Despite difficulties in precisely defining the phenomenon of energy poverty, it seems necessary to adopt clear criteria for this phenomenon simple and narrow definition may treat it as the lack of funds for the purchase of energy to satisfy the basic needs of the household to the extent necessary for its normal functioning. Thus households regarded as affected by energy poverty are those which spend on electricity, gas and other fuels more than $10 \%$ of their disposable income. This limit should not be absolute due to the variety of energy needs which mostly depend on the size and thermal performance of the dwelling and the number and lifestyle of the residents.

\section{FACTORS AFFECTING THE LEVEL OF ENERGY POVERTY IN TERMS OF HEAT ENERGY ON EXAMPLE OF POLAND}

Heat is one of the basic energy carriers used at homes. The energy usually comes from district heating (in urban households) or firewood and hard coal (in rural households). The usage of energy carriers has been presented in Figure 2.

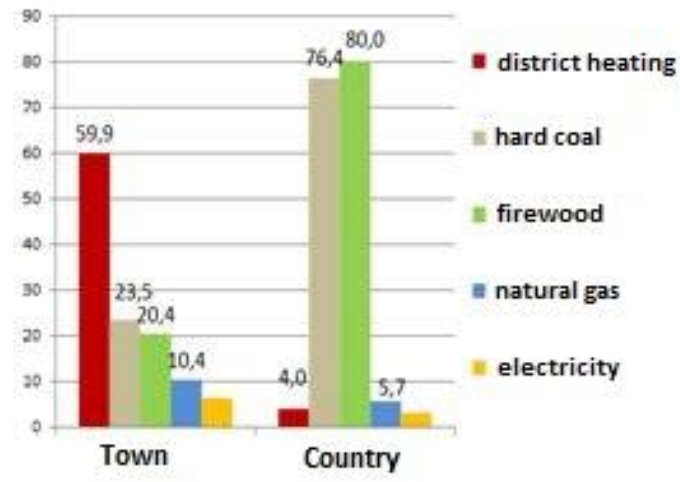

Figure 2. The range of energy carriers used by the households.

This energy is mainly used for heating rooms and water and for cooking. Figure 3 presents the amount of energy consumed for particular purposes.

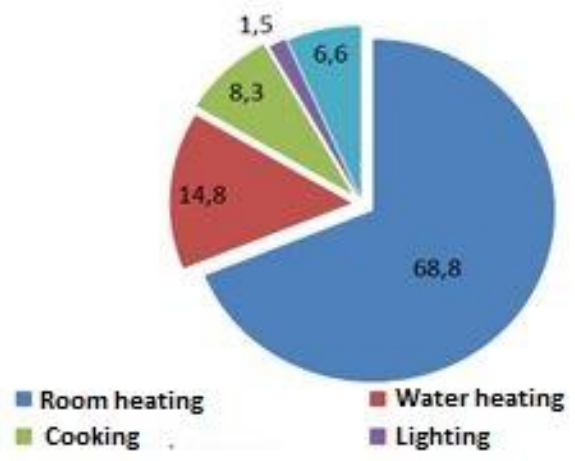

Figure 3. Structure of heat consumption in the households.

The studies and many surveys carried out in the households confirm that they face some difficulties in the free use of heat energy. This is what we call energy poverty having its source in some significant factors which, among many others, are: prices of energy, technical condition of buildings - their structure, i.e. energy efficiency (heat efficiency) - housing area, climate and environmental context, behaviour and preferences of the household. Due to the limited possibility to analyze the problem I will focus only on some of them. 
The first critical determinant of energy poverty is the price of energy which compared to the prices of other goods is now the highest in Europe. In 2016 the costs of energy have increased by 5.6 percent while being often not proportionate to the household financial income. The increase in both wholesale and retail nominal prices of energy is related to, among others, the need of modernizing the whole structure of Polish power industry, which is in a terrible condition. As Minister Krzysztof Tchórzewski informed, in order to provide power plants with capital for required investments, such as more ecological electricity production, exhaust filters and much more, the Ministry of Energy took steps to raise additional 10 billion zlotys (PLN) from energy companies. The need for modernization of Polish power industry results also from the European Commission's requirements, which in its "clean energy" strategy related to the implementation of the climate and energy package assumes that by 2030: the electricity consumption must be reduced by 30 percentage, 27 percent of consumed energy shall come from renewable sources, state aid for coal blocks shall be abolished, and carbon dioxide $\left(\mathrm{CO}^{2}\right)$ emissions for coal-fired power plants shall be limited at 550 grams per kilowatt-hour (kWh). Without investing in these fields Poland will not meet the above requirements. Low wholesale energy prices have been so far the favorable circumstances for taking up these actions and prompted the Ministry to raise the necessary funds in this source. However, despite good intentions, conducted policy has a severe impact on "ordinary" households as it affects the increase in the transmission fee, which is added to each electricity bill regardless of the household energy consumption. In 2016 the price for energy was 3.87 zlotys (PLN) and since 2017 this price is 8 zlotys, which is twice as much. On a yearly basis the household will have to pay 96 zlotys (PLN) when compared to 2016 it was 49.56 zlotys (PLN). Thus, the energy bill of an average four-person household having, e.g. an apartment up to $50 \mathrm{~m}^{2}$, may be by approximately $20-25$ zlotys (PLN) higher per annum. In the case of bigger dwellings, the increase in prices for energy will be even more noticeable. In other words, it can be easily seen that the need for modernization of Polish energetic system is inevitably related with transferring to the households some costs incurred by the energy companies.

Second critical determinant of energy poverty in terms of heat, which is connected with charged price for energy, is the energy efficiency of the buildings. It consists of: the quality of thermal insulation, the tightness of windows, balcony doors, and roof, the condition of technical equipment and installation, ventilation and many others. Studies show that many buildings (single-family houses, townhouses, blocks of flats) still require thorough thermal modernization as well as replacement of equipment and systems for production, regulation, storage and transport of heat causing much loss of heat energy. In other words, they are not favorable to maintain the rational level of heat consumption. For instance, in an energy-consuming singlefamily building the heat loss amounts: through the windows - 36.3 percent, through inefficient ventilation - 30.5 percent, through the external walls - 13.3 percent, through the roof -
13.3 percent, through the floor on the ground -4.9 percent, through external doors -1.8 percent.

The housing area is also important as the lower the efficiency of the above-mentioned components of building energy efficiency is, the higher costs of providing the required comfort of heat in winter or cool in summer are. Those costs are the higher, the larger the area of the dwelling is. For instance, a 10 percent bigger apartment increases heating costs by 4 percent. This difference can also be seen between cities or towns and the country: $10 \%$ larger apartments generates an increase in heating costs respectively by 3.2 percent in the city/town and 1.2 percent in the country. The energy efficiency of buildings and the associated costs for heat are also clearly visible on the basis of the age of the buildings. The newer buildings, the greater their energy efficiency, and therefore the lower the cost of heat. For instance, households residing in the buildings built after 2006 pay less even by 17 percent then the residents of the buildings built earlier. However this relation of energy costs and the age of buildings is characteristic only for the city/town. In the country the situation is different. Costs for energy incurred by the households residing in older buildings are lower than in younger buildings, i.e. built after 2006. For instance, residents of dwellings built till 1960 pay less by 8 percent for heat energy than residents living in buildings built between 1960-80. Even higher heat prices (by 10 percent) are paid by households living in buildings built after 2006. The reason for this paradoxical phenomenon are probably unheated apartments in older dwellings, it means, greater savings on the comfort of felt heat [8].

Furthermore, it is worth noting that the price for heat energy is also influenced by the type of property ownership. The owners of the dwellings spend 10 percent less on heating than households residing in social housings that are owned by the municipality. Another factor that determines the costs of heat for households, and thus affects their experience of energy poverty, is the behavior and preferences of the users. For example, the elderly and children have slightly different preferences in terms of perceived heat comfort - i.e. higher (and higher costs) than adults and working people - i.e. lower (and lower costs). Another example are working people whose energy needs are lower due to the small amount of time spent in the apartment. Energy poverty may also be deepened by inappropriate, unreasonable usage of heat energy. Examples include ventilation of an apartment (open windows) with the radiator turned on, overheating rooms, excessive use of air conditioning (cold production) in the summer, uneconomic use of heat and much more [9].

\section{Consequences of Energy Poverty Affecting THE LEVEL OF SOCIAL SECURITY}

The consequences of energy poverty on the level of social security understood as the state of freedom from threats, lack and deprivation in various aspects of human life (negative perception) as well as the state of satisfying and protection of basic living conditions and standards that are important for human existence - are very significant and 
much visible in various aspects. Research in the UK shows that rising energy and gas prices by only 1 percent increases the energy poverty by even 40 percent. Its effects are primarily seen in the weakening of physical health especially among children, the elderly and the chronically ill. Persistent cold or even chill in the apartment as well as the consequent dampness may lead to respiratory problems such as asthma or bronchitis. Another significant consequence of energy poverty is its negative impact on human mental health. Aforementioned housing conditions resulting from energy poverty can cause fear and even anxiety, may weaken neighborhood or family relationships leading consequently to further low self-esteem and social exclusion or isolation. Another effect of energy poverty is the destruction or even degradation of buildings caused by low temperature and humidity in the building. Improper insulation of windows, walls or doors leads to increased heat loss. The more deteriorated the housing conditions are, the harder it is to keep the temperature at the adequate level and thus to stop the damp process. The energy debt to the heat supplier is also regarded as a consequence of energy poverty. Its usually presumed sources are: low financial income of households which are not able to pay for their heating bills on a regular basis, and the low energy efficiency (a lack of tightness) of a building causing heat escape, consequential increase in heat consumption and thus higher costs for heat, and finally outdated and uneconomic heating installation (heating system). It should be noticed that the need to pay high energy bills leads to reduction in household incomes, which could be spent on other essential goods, such as food, clothing, rest, transportation, etc. The major consequence of energy poverty is also increased carbon dioxide emission whose visible effect - smog, was felt even this year in winter almost everywhere in Poland. The increased amount of carbon dioxide $\left(\mathrm{CO}^{2}\right)$ emission has the same sources as above. Those are: low energy standard of the building causing increase in energy consumption; low financial income of households, which are not able to purchase better heat fuel and thus are forced to use fuel of lower quality; and related high price of heat energy [10].

\section{CONCLUSION}

The phenomenon of energy poverty undoubtedly affects the level of social security and expresses it at the same time. This fact shows the importance and complexity of the problem. It is so significant because so+cial security is or should be seen as a public good belonging to the public property of a state governed by public law. It cannot be marketed, shared or operate selectively. It should be built in such a way on the basis of and considering public interest and common welfare in both material and immaterial sphere, whose foundations are custom, morality and law. What is more, the security should be subject to supervision and special protection by the state.

Social security as a public good is characterized by universality, generality, social significance and usefulness. At this point, I should note that conducted research and the analysis of impact of energy poverty on the level of social security as a universal good are not easy to carry out as the security refers to subjective and individual feelings and is subject to constant relativization in time and space. Nevertheless, the analysis of individual needs, however repetitive, leads to the development of general norms and principles of actions to be taken. Such needs are a guideline for the development of state duties and institutional and legal framework for the protection of a given good. Fulfilling individual needs provides often to satisfying collective needs while achievement of a public purpose may involve satisfying the repetitive common interests of the individuals and the benefits of it are derived, even indirectly, by the functional connections existing in the society. Therefore, the research on impact of energy poverty on the level of social security in terms of individual needs and the interests of households does not disqualify this term as a public good. Indeed, the meaning of any good is built in order to relate it to the situation of specific individuals or groups, and abstract safety construction by abstract eliminating the sources of threats has no reference to the people and thus no value.

\section{REFERENCES}

[1] Defra, Business, Enterprise and Regulatory Reform (BEER). (2008). "Fuel Poverty Statistics Annex", p. 40.

[2] M. Lis \& A. Miazga. (2015). „Dynamiczne własności miar ubóstwa energetycznego", Instytut Badań Strukturalnych (IBS) Research Report, No. 1/2016, p. 28.

[3] A. Bieńkuńska \& K. Sobestjański. (2013). "Ubóstwo w Polsce w świetle badań Głównego Urzędu Statystycznego GUS”. Warszawa: Zakład Wydawnictw Statystycznych (ZWS), p. 27.

[4] A. Miazga \& D. Owczarek. (2015). "Dom zimny, dom ciemny - czyli ubóstwo energetyczne w Polsce”, Instytut Badań Strukturalnych (IBS) WORING ARES, No. 16/2015, p.13.

[5] C. Aron, J. Kostrzewa, D. Owczarek \& E. Świdrowska. (2013). "Poland: Making energy efficiency investments vailable to the poor". Washington: Internal report of the World Bank, p. 17.

[6] D. Owczarek \&A. Miazga. (2015). "Ubóstwo energetyczne w Polsce - definicja i charakterystyka społeczna grupy". Warsaw: Instytut na Rzecz Ekorozwoju, p. 22.

[7] A. Miazga \& D. Owczarek. (2015). "Dom zimny, dom ciemny - czyli ubóstwo energetyczne w Polsce". IBS WORING PARES, No. $16 / 2015$, p. 7.

[8] M. Lis \& A. Miazga, Kogo obciąży wzrost cen energii. Mapa wydatków energetycznych Polaków. Instytut Badań Strukturalnych (IBS) Working Paper, No. 11/2015, p. 18.

[9] M. Lis \& A. Miazga, Kogo obciąży wzrost cen energii. Mapa wydatków energetycznych Polaków. Instytut Badań Strukturalnych (IBS) Working Paper, No. 11/2015, p. 19.

[10] I. Figaszewska. (2009). "Ubóstwo energetyczne - co to jest?". Bulletin of the Energy Regulatory Office, No. 5 (67), p. 7. 